\title{
Production of Cashew Rootstocks Submitted to Organic and Mineral Fertilization
}

\author{
Valéria F. de O. Sousa ${ }^{1}$, Gisele L. dos Santos ${ }^{1}$, Marília H. B. Rodrigues ${ }^{1}$, Sennyone F. Pimenta ${ }^{2}$, Genilson L. Diniz ${ }^{2}$, \\ Michel D. S. Ribeiro ${ }^{2}$, Agda M. F. de Oliveira ${ }^{2}$, José J. F. dos Santos ${ }^{2} \&$ Rosilene A. da Silva $^{2}$ \\ ${ }^{1}$ Academic Unit of Tropical Horticulture, Federal University of Campina Grande, Pombal, PB, Brazil \\ ${ }^{2}$ Academic Unit of Agricultural Science, Federal University of Campina Grande, Pombal, PB, Brazil \\ Correspondence: Valéria F. de O. Sousa, Academic Unit of Tropical Horticulture, Federal University of Pombal, \\ Paraíba, Brazil. Tel: 55-083-99943-1191. E-mail: valeriafernandesbds@gmail.com
}

Received: January 11, 2018 Accepted: February 24, $2018 \quad$ Online Published: March 15, 2018

doi:10.5539/jas.v10n4p392 URL: https://doi.org/10.5539/jas.v10n4p392

\begin{abstract}
The use of grafted seedlings is a cultural practice that aims at the optimization of agricultural production, and materials of organomineral added to the substrate can help in the well development. The aim of this study was to evaluate the effect of the application of increasing doses of organic and mineral material on the development of cashew rootstocks. The test was conducted in the experimental area of the Federal University of Campina Grande (UFCG), campus Pombal-PB in the period from July to September 2017. The treatments were constituted of five increasing doses of organic matter $(0,100,200,300$ and $400 \mathrm{~g}$ of bovine manure) and four levels of mineral fertilizer $(0,1,2$ and $3 \mathrm{~g}$ of NPK). The design was in randomized blocks, distributed in factorial $5 \times 4$, with 4 replications. For the planting, it was used creole seeds originary of the city of Livramento do Cariri Paraibano and substrate composed by sand texture Franco sandy. At 60 days after sowing, the following variables were analyzed: plant height $(\mathrm{cm})$, leaf diameter $(\mathrm{mm})$, number of leaves, leaf area $\left(\mathrm{cm}^{2}\right)$, fresh and dry mass, leaf, stem, shoot (g), percentage of biomass (\%) and quality index of seedlings. Based on the results obtained, it is concluded that the organic and mineral combination ( $1 \mathrm{~g}$ of NPK and $200 \mathrm{~g}$ of bovine manure) provided the greatest increases in vegetative growth characteristics and quality of rootstocks in the cashew tree.
\end{abstract}

Keywords: Anacardium occidentale L., mineral fertilizer, bovine manure

\section{Introduction}

The cashew tree (Anacardium occidentale L.), is a culture that has your center of origin in the Northeast of Brazil, where is very adapted to the semi-arid conditions, and as consequence produces nutritious pseudofruits, that present great appreciation mainly in the local market (Araújo, 2013). This cultivation represents great importance in socioeconomic terms, since in addition to the pseudofruit, since products such as the almond present in the chestnut and the liquid coming from the bark are included as raw material for industries (Ferreira et al., 2016a).

The productivity of cashew nuts in Brazil in the 2016 harvest was 228,796 tha-1 (IBGE, 2016). In the Northeast, farms and agribusiness located in urban areas are benefiting from the cashew cultivation and extraction of brown, forming thus and activity that provides income generation, employment and development, especially in states such as Ceará, Rio Grande do Norte and Piauí (Araújo, 2013, 2014).

However, because the cashew is a heterozygous species, if it was propagated with seed, there will be the formation of plants with different genotypes and phenotypes, resulting in diferent orchards (due to high fruit variability and lack of synchrony during its development phases), low productivity and increased costs, thus hindering the commercial exploitation of caju or to be processed (Cavalcanti Junior, 2013).

Grafting, however, is a method that has been used to allow species reproduction, preserving desirable characteristics such as greater uniformity, precocity and fruit quality (Ferreira et al., 2016b). However, it is understood that, to the good development of rootstocks, it is crucial that favorable nutritional conditions are offered to it.

Sources of organic or mineral fertilizers have been used for the formulation of substrates, highlighting the use of bovine manure as an organic fertilizer. According to Aguiar et al. (2017), this resource has easy access and low 
cost to the producer, favors substrate drainage, increases water retention capacity, stimulates root system development, and provides nutrients in a graduated way. While, the use of NPK (Nitrogen, Phosphorus and Potassium) mineral fertilizers due to its composition of essential macronutrients expresses strong influence on the good development of the plants, however, it has a fast leaching. Thus, the associated use of an organic and mineral source becomes one of the alternatives to increase the efficiency of the fertilizer (Oliveira Neto et al., 2017).

Few studies deal with organomineral fertilization for seedling production in cashew tree cultivation, mainly in relation to rootstock. In this sense, the objective of this study was to evaluate the effect of the application of increasing doses of organomineral material on the development of cashew rootstocks.

\section{Material and Methods}

The experiment was conducted from September to November 2017 in the experimental area of the Center of Science and Technology Agrifood of the Federal University of Campina Grande, Pombal-PB, whose reference coordinates are: latitude $6^{\circ} 46^{\prime} 12^{\prime \prime} \mathrm{S}$, longitude $37^{\circ} 48^{\prime} 7^{\prime \prime} \mathrm{W}$ and $184 \mathrm{~m}$ of altitude at sea level. The city of Pombal is located in the semi-arid northeast of Brazil, according to the classification of Köppen (1948), the climate of the region is type hot and humid with average annual precipitation of $431.8 \mathrm{~mm}$, with average temperature of $35 \pm 5{ }^{\circ} \mathrm{C}$ and mean relative humidity $40 \pm 15 \%$.

The rootstocks produced in this assay resulted in native seeds, suplied from cashew producers of the Livramento Cariri and in the region. The seeds were initially subjected to the density test, and emerged for 24 hours in water to select those with higher density, eliminating the less dense floaters, considering the potential of lower germination. A sandy Franco texture soil was used, collected in the $0-30 \mathrm{~cm}$ depth range, on the Pombal-PB campus. The results of the soil analysis are shown in Table 1 .

Table 1. Physical and chemical characteristics of the soil used in the experiment, Pombal-PB, 2017

\begin{tabular}{|c|c|c|c|c|c|c|c|}
\hline \multicolumn{8}{|c|}{ Chemical Characteristics } \\
\hline $\mathrm{pH}$ & C.E & $\mathrm{P}$ & $\mathrm{K}$ & $\mathrm{Na}$ & $\mathrm{Ca}$ & $\mathrm{Mg}$ & Organic matter \\
\hline $\mathrm{H}_{2} \mathrm{O} 1: 2.5$ & $\mathrm{dS} / \mathrm{m}^{-1} 1: 5$ & $\mathrm{mg} / \mathrm{dm}^{3}$ & \multicolumn{4}{|c|}{------------------ $\mathrm{cmol}_{\mathrm{c}} / \mathrm{dm}^{3}$------------------ } & --------- g kg$^{-1}$--------- \\
\hline 7.41 & 1.21 & 17 & 0.28 & 2.21 & 5.4 & 4.1 & 32 \\
\hline \multicolumn{8}{|c|}{ Physical Characteristics } \\
\hline Sand & Silte & Clay & \multicolumn{2}{|c|}{ Density apparent } & \multicolumn{2}{|c|}{ Total porosity } & Classification of texture \\
\hline ------------- & $\mathrm{g} / \mathrm{K}^{-1}$ & -------- & \multicolumn{2}{|c|}{------- $\mathrm{g} \mathrm{cm}^{-3}$} & \multicolumn{2}{|c|}{-------- \% --------- } & \\
\hline 734 & 176 & 90 & 1.38 & & 47. & & Sandy franc \\
\hline
\end{tabular}

Note. $\mathrm{pH}=\mathrm{pH}$ of the substrate; $\mathrm{CE}=$ Electrical conductivity.

The fertilization was performed two days before planting, incorporated to the soil organic matter and mineral components, urea, triple superphosphate and potassium chloride, as Ximenes (1995), recommendations being the source of used organic matter the bovine manure, the analysis is in the Table 2.

Table 2. Chemical analysis of Bovine Spittle used in the experiment. Pombal-PB, 2017

\begin{tabular}{|c|c|c|c|c|c|c|c|c|c|c|c|}
\hline \multicolumn{12}{|c|}{ Characteristics Chemicals } \\
\hline $\mathrm{Ph}$ & EC & $\mathrm{P}$ & $\mathrm{K}$ & $\mathrm{Na}^{+}$ & $\mathrm{Ca}$ & $\mathrm{Mg}$ & $\mathrm{Al}$ & $\mathrm{H}+\mathrm{Al}$ & SB & $(\mathrm{T})$ & MO \\
\hline $\mathrm{H}_{2} \mathrm{O} 1: 2,5$ & $\mathrm{dS} / \mathrm{m}^{-1} 1: 5$ & $\mathrm{mg} / \mathrm{dm}^{3}$ & \multicolumn{6}{|c|}{---------------------- $\mathrm{cmol}_{\mathrm{c}} / \mathrm{dm}^{3}$------------------ } & \multicolumn{2}{|c|}{$--\mathrm{cmol}_{\mathrm{c}} / \mathrm{dm}^{3}$-- } & $\mathrm{g} \mathrm{kg}^{-1}$ \\
\hline 7.82 & 1.00 & 29.0 & 1.56 & 1.68 & 4.2 & - & 0.0 & 0.0 & 7.16 & 7.16 & 4.5 \\
\hline
\end{tabular}

The experiment was conducted in a randomized block design in factorial scheme $5 \times 4$, consisting of 5 levels of organic matter and 4 levels of mineral fertilization (NPK), repeated 4 times, and totaling 80 plants. The organic fertilizer was distributed in the proportion of $0,10,20,30$ and $40 \%$ of the weight of the substrate contained in the container, equivalent to $0,100,200,300$, and $400 \mathrm{~g}$ of bovine manure $1 \mathrm{~kg}$ of soil, respectively, since the mineral fertilization consisted of $0,0.1,0.2$ and $0.3 \%$ of the weight of the substrate contained in the recipient, 1 , 2 and $3 \mathrm{~g}$ of Nitrogen, Phosphorus and Potassium-NPK/1 kg of soil, using as urea source $(44 \% \mathrm{~N})$, triple 
superphosphate $\left(41 \% \quad \mathrm{P}_{2} \mathrm{O}_{5}\right.$ and $\left.12 \% \mathrm{Ca}\right)$ and potassium chloride $\left(60 \% \mathrm{~K}_{2} \mathrm{O}\right)$ in the proportion $10-20-30$, respectively.

The siege was carried out directly in containers (bags of black polyethylene with dimensions of $20 \mathrm{~cm}$ wide by $35 \mathrm{~cm}$ in length), with capacity for $2 \mathrm{~kg}$ of substrate, bored laterally, being sown a single seed per container with the bas and turned up to a depth of $3.0 \mathrm{~cm}$, as recommended by Barros et al. (1993). The experiment was conducted in a protected environment (greenhouse) for a period of 60 days after sowing. Cultural treatments were limited to irrigation and weed control, as no pest and disease attack was observed during experimental co-cultivation.

At 60 days after sowing, the following evaluations were performed: plant height $(\mathrm{cm})$, (measured from the cervix to the apical bud); diameter of the stem (mm) (measured at a distance of $5.0 \mathrm{~cm}$ from the collar); number of leaves (number of leaves larger than $5.0 \mathrm{~cm})$; and leaf area $\left(\mathrm{cm}^{2}\right)$ according to Equation 1:

$$
\mathrm{AF}=0.21+0.69 \mathrm{LC} \quad\left(\mathrm{R}^{2}=0.97\right)
$$

Where, $\mathrm{L}=$ leaf width; $\mathrm{C}=$ leaf length (Murthy et al., 1985).

The fresh masses (leaf, stem and shoot) were also checked in analytical balance. After that, the dry mass (leaf, stem and aerial part) was determined, with drying in forced air circulation at $65{ }^{\circ} \mathrm{C}$, until constant mass, being expressed in g plant $^{-1}$.

Subsequently, the percentage of biomass (PB) was calculated according to the Emon et al. (2015) method, expressed by Equation 2:

$$
\mathrm{PB}=\mathrm{MST} / \mathrm{MFT} \times 100
$$

Where, MST $=$ total dry mass of the plant and MFT $=$ total fresh mass of the plant.

It was also calculated the quality index of seedlings according to Dickson et al. (1960) using the dry mass of shoot and root, total dry mass, height and diameter of seedlings, according to Equation 3:

$$
\mathrm{IQD}=\mathrm{MST} /[(\mathrm{H} / \mathrm{D})+(\mathrm{MSPA} / \mathrm{MSR})]
$$

Where, MST = total dry mass $(\mathrm{g}) ; \mathrm{H}=$ height $(\mathrm{cm})$; DC = lap diameter $(\mathrm{cm})$; MSPA = shoot dry mass $(\mathrm{g})$; MSRA $=$ root dry mass $(\mathrm{g})$.

The data referring to the variables measured were subjected to the $\mathrm{F}$ test at $0.05 \%$ significance by means of analysis of variance and the means of the variables were submitted to regression analysis. For the accomplishment of the statistical tests, the available resources were utilized in the Computational System of Statistical Analysis-SISVAR 5.6 (Ferreira, 2011).

\section{Results and discussion}

Cashew tree seedlings at 60 days after sowing had a significant interactive effect at $1 \%$ probability $(\mathrm{p} \leq 0.01$ and $\leq 0.05$ ) for all variables analyzed, demonstrating that both organic and mineral fertilization interfered in the development and qualities of the seedlings, except in the stem diameter that meant only for the organic input (Table 3). 
Table 3. Summary of the variance analysis table of cashew tree seedlings under organic and mineral fertilization. UFCG, Pombal-PB, 2017

\begin{tabular}{|c|c|c|c|c|c|c|c|}
\hline \multirow{2}{*}{ SV } & \multirow{2}{*}{$\mathrm{DF}$} & \multicolumn{6}{|c|}{ Mean square } \\
\hline & & HEIG $(\mathrm{cm})$ & DIAM (mm) & NL & $\mathrm{LA}\left(\mathrm{cm}^{2}\right)$ & FLM (g) & $\mathrm{LDM}(\mathrm{g})$ \\
\hline Organic & 4 & $84.483^{* *}$ & $0.5969^{* *}$ & $5.825^{* *}$ & $3034841.131^{* *}$ & $7.530^{* *}$ & $0.4126^{* *}$ \\
\hline Mineral & 3 & $30.159^{* *}$ & $0.3252^{\mathrm{ns}}$ & $7.012^{* *}$ & $3746903.525^{* *}$ & $13.616^{* *}$ & $1.4835^{* *}$ \\
\hline $\mathrm{O} * \mathrm{M}$ & 12 & $7.374^{* *}$ & $0.1194^{\mathrm{ns}}$ & $1.658^{* *}$ & $1302190.746^{* *}$ & $2.343^{\mathrm{ns}}$ & $0.2342^{* *}$ \\
\hline Block & 3 & $1.145^{\mathrm{ns}}$ & $0.456^{\mathrm{ns}}$ & $0.412^{\mathrm{ns}}$ & $227644.708^{\mathrm{ns}}$ & $0.225^{\mathrm{ns}}$ & $0.092^{\mathrm{ns}}$ \\
\hline Residue & 57 & 0.999 & 0.146 & 0.579 & 189532.688 & 0.307 & 0.092 \\
\hline CV $(\%)$ & & 5.67 & 10.51 & $9.10^{-}$ & 16.03 & 8.53 & 15.93 \\
\hline \multirow{2}{*}{ F.V. } & \multirow{2}{*}{ DF } & \multicolumn{6}{|c|}{ Mean square } \\
\hline & & FDC (g) & $\mathrm{DMC}(\mathrm{g})$ & FRM (g) & DMR (g) & PB (\%) & DQI (\%) \\
\hline Organic & 4 & $9.2466^{* *}$ & $0.2270^{* *}$ & $3.3851^{* *}$ & $0.210856^{* *}$ & $79.7943^{* *}$ & $0.764769^{* *}$ \\
\hline Mineral & 3 & $0.0524^{\mathrm{ns}}$ & $0.0719^{* *}$ & $6.1212^{* *}$ & $0.758018^{* *}$ & $13.5643^{* *}$ & $0.502898^{* *}$ \\
\hline $\mathrm{O} * \mathrm{M}$ & 12 & $1.696^{* *}$ & $0.1628^{* *}$ & $1.0534^{* *}$ & $0.119686^{* *}$ & $30.4906^{* *}$ & $0.123434^{* *}$ \\
\hline Block & 3 & $0.106^{\mathrm{ns}}$ & $0.0267^{*}$ & $0.1014^{\mathrm{ns}}$ & $0.047347^{\mathrm{ns}}$ & $2.9013^{\mathrm{ns}}$ & $0.005097^{\mathrm{ns}}$ \\
\hline Residue & 57 & 0.188 & 0.0086 & 0.1383 & 0.047359 & 2.6280 & 0.008119 \\
\hline CV (\%) & & 12.11 & 9.79 & 8.53 & 15.93 & 5.50 & 11.60 \\
\hline
\end{tabular}

Note. Plan height (HEIG), diameter (DIAM), number of leaves (NL), leaf area (LA), fresh leaf mass (FLM), leaf dry mass (LDM), fresh dough of caule (FDC), dry mass of caule (DMC), fresh root mass (FRM), dry mass of the root (DMR), percentage of biomass (PB) and quality index of Dickson (DQI).** Significant at $1 \%$; * significant at $5 \%$ probability by $\mathrm{F}$ test; ${ }^{\text {ns }}$ not significant.

In plant height, there was a quadratic behavior for all doses of mineral fertilizer, but the dose of $1 \mathrm{~g}$ of NPK was superior to the others when used $200 \mathrm{~g}$ of manure, reaching $21.12 \mathrm{~cm}$ (Figure 1A). Fertilization organomineral presents promising results in the production of seedlings, Carneiro et al. (2011) when evaluating the production of rootstock of lemon clove in response to organomineral fertilization observed that there was an increase in the growth variables evaluated. This suggests that even organic matter with a late effect related to mineral fertilization produces satisfactory effects, allowing the reduction of costs for seedling production, since mineral fertilizer can be partially reduced if organic matter is combined, contributing for the initial development of cashew tree seedlings.

Meanwhile, for the stem diameter, there was a quadratic behavior along the increase of doses of bovine manure, regardless of the doses of mineral fertilizer, with a maximum point in the estimated dose of $72 \mathrm{~g}$ of manure equivalent to $3.77 \mathrm{~mm}$ in diameter, with $9.81 \%$ reduction from that dosage to the $400 \mathrm{~g}$ dose of manure (Figure 1B).
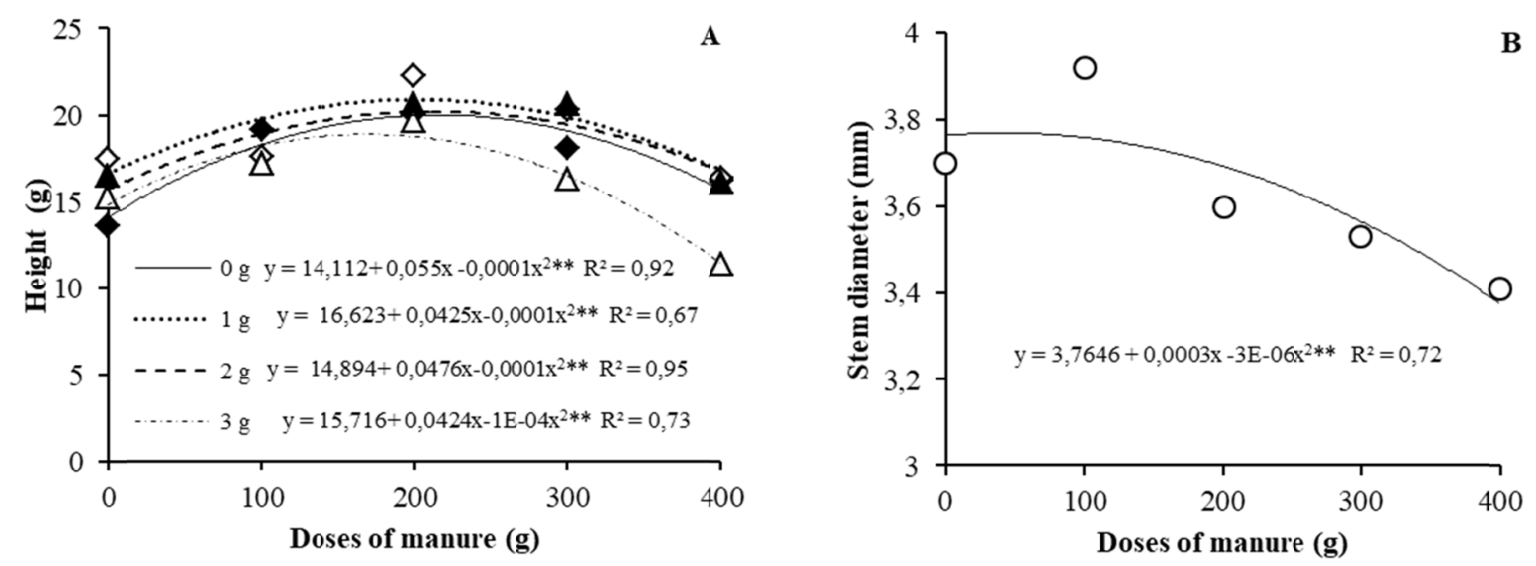

Figure 1. Plant height and diameter cauli in cashew tree seedlings submitted to organic and mineral fertilization. UFCG, Pombal-PB, 2017 
Probably, the manure ratios above this dosage were high and did not provide positive effects on this variable. Both the height and the caulinar diameter are variables that provide an increase in thephytomass production of the plant, being relevations for the process of seedling production (Melo et al., 2007).

Bovine manure increases the water retention capacity of sandy soils, provides nutrients, enhances microbial activity, improves soil buffering power and modifies $\mathrm{pH}$ (Chang et al., 2007). On the other hand, the supply of excess organic matter can cause deleterious effects. Similar behavior was founded by Cavalcante et al. (2011) when evaluating organic fertilization on initial growth in pitaya, observing that the higher doses of organic fertilizer decreased the caulinar diameter.

The foliar emission and foliar area were affected by organic and mineral fertilization, showing that the number of leaves had a linear decreasing behavior with increase of the manure dosage in the absence of mineral fertilizer and at the dose of $1 \mathrm{~g}$, with respective reductions of 20,21 and 12.69\%. At the dose of $2 \mathrm{~g}$ of NPK no significant impact, however, the dosage $3 \mathrm{~g}$ behaved quadratically with aproximataly 8 sheets at a dose of $184 \mathrm{~g}$ manure, declining from this dosing (Figure 2A). Divergent results were found by Pereira et al. (2011), where the increase in the concentration of the mineral source occurred the reduction of the number of leaves of pitombeira rootstocks.
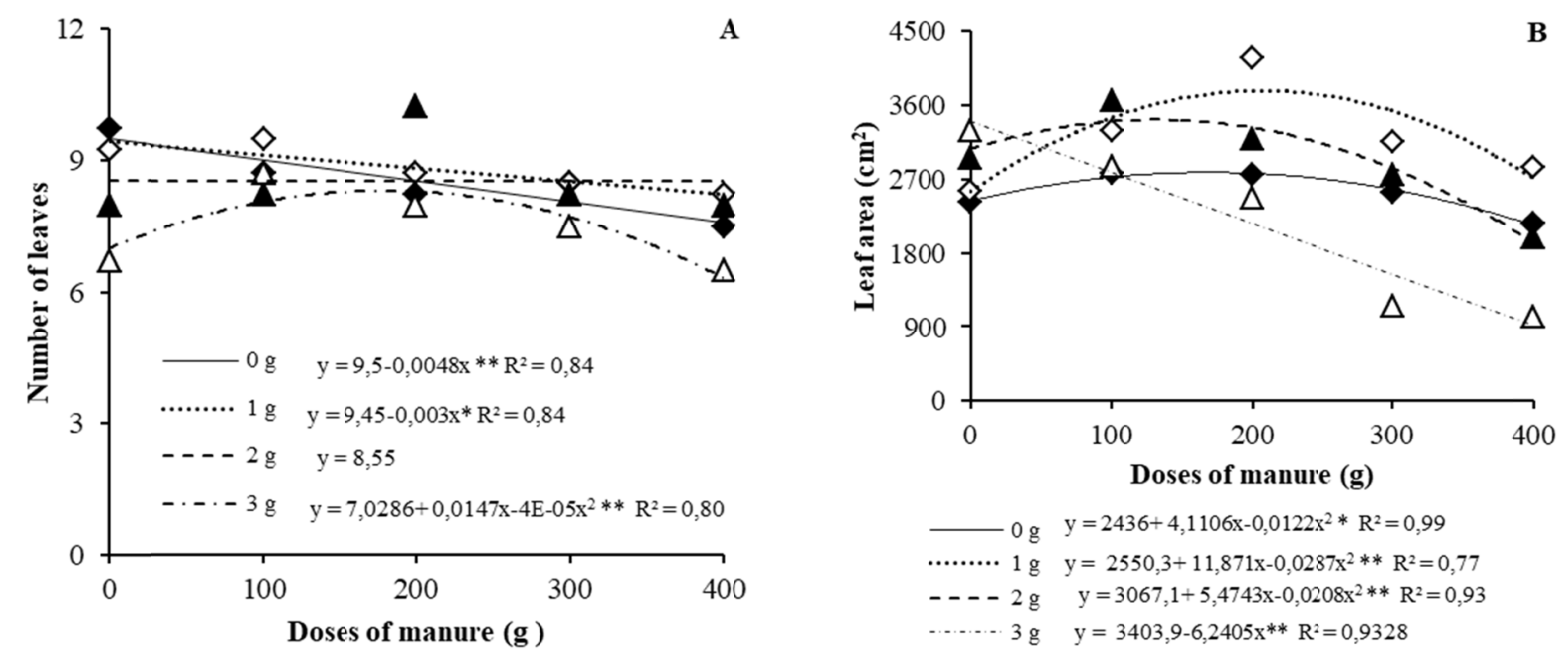

Figure 2. Number of leaves (A) and leaf area (B) in cashew tree seedlings submitted to organic and mineral fertilization. UFCG, Pombal-PB, 2017

In the foliar area (Figure 2B), was observed that in the absence of NPK the seedlings presented $2782.24 \mathrm{~cm}^{2}$ at a dose of $168 \mathrm{~g}$ manure, while the dose of $1 \mathrm{~g}$ NPK associated with manure reached $207 \mathrm{~g} 3777.83 \mathrm{~cm}^{2}$, for the dosage of $2 \mathrm{~g}$ of NPK with that of $132 \mathrm{~g}$ of manure, $3427.28 \mathrm{~cm}^{2}$ was obtained, and when the dosage of $3 \mathrm{~g}$ of NPK was used, there was a behavior inversely proportional to the increase of the doses of manure, equivalent to a reduction of $18.33 \%$ per $100 \mathrm{~g}$ of manure.

In this way, the increase of the organic matter in the substrate of the seedlings provided positive effects for the doses of NPK, however, the latter in excess caused possible toxicity, since there was a significant decrease for this variable. According to Taiz et al. (2017), inadequate supply of plant essential elements cause disturbances in metabolic processes, resulting in abnormal plant functioning.

According to regression analysis for the variable fresh mass of the sheet, the mathematical model who best explained was the linear one for the concentration of $0 \mathrm{~g}$ of NPK, already the quadratic equation was the one who best fit the other doses of NPK evaluated in function of the averages observed for the curve. Therefore, it is denoted that it was not observed significant difference at a dose $0 \mathrm{~g}$ NPK depending on the manure doses, but there was an increase in these contents at doses of 1,2 , and $3 \mathrm{~g}$ of NPK, which reached maximum $(8.85,7.18$ and $6.18 \mathrm{~g}$ respectively) when the dose of $20 \mathrm{~g}$ of manure was applied, thereafter reduction was observed as the dose of manure was increased (Figure 3A). A similar result was observed by Costa et al. (2008) studying the effects of organic and mineral fertilization on biomass production and essential oil of Cymbopogon citratus observed a positive tendency in the fresh mass of these plants, in which it obtained better performance when these two inputs were associated. 

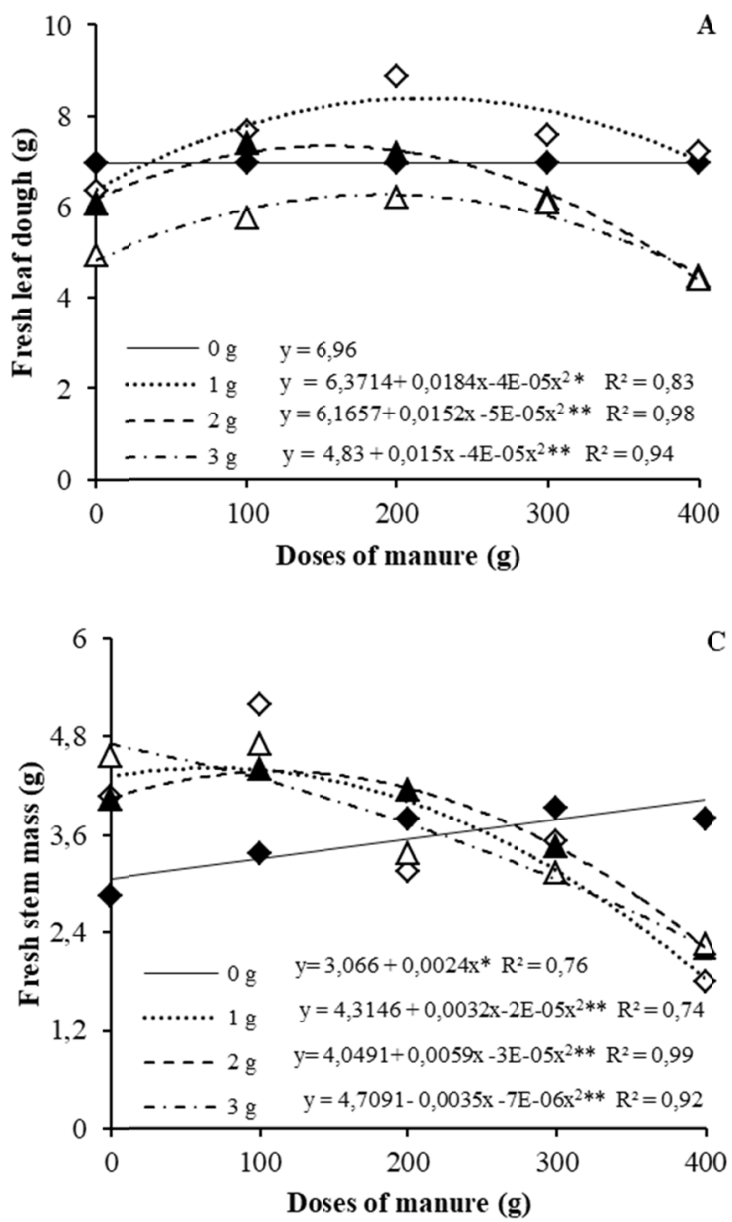
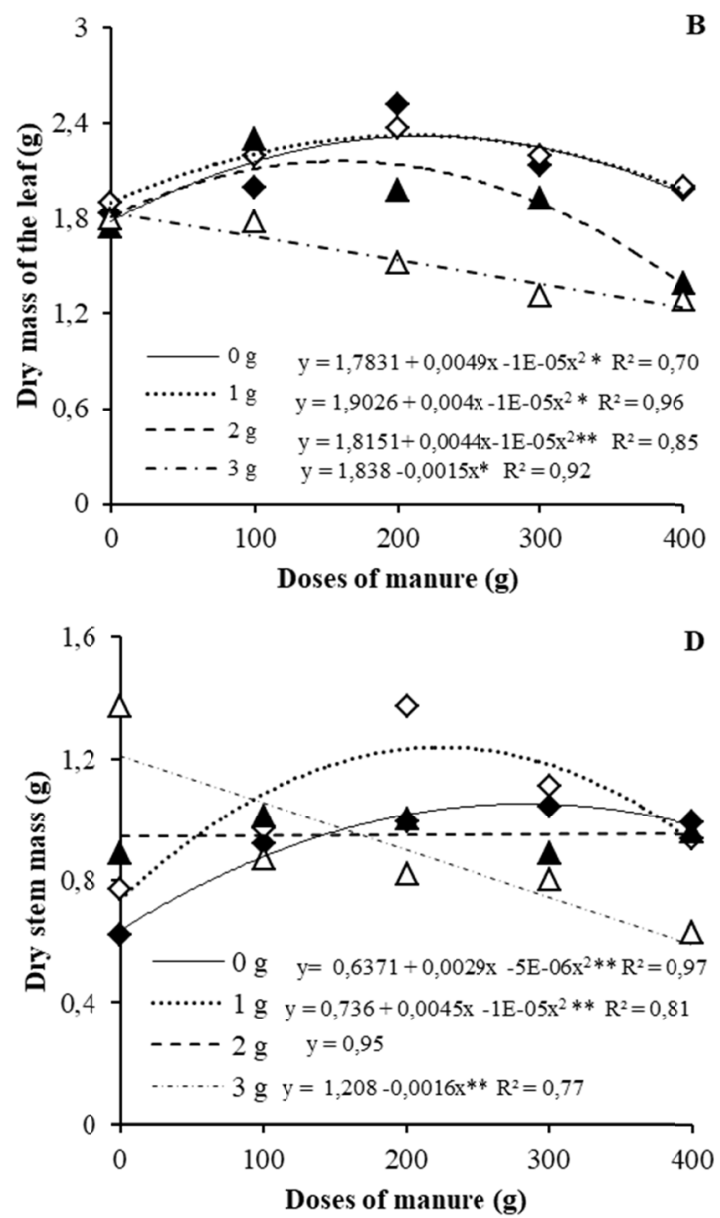

Figure 3. Fresh (A) and dry (B) mass of the leaf, fresh (C) and dry (D) mass of the stem of cashew tree seedlings submitted to organic and mineral fertilization. UFCG, Pombal-PB, 2017

According to the dry mass data of the leaves, a quadratic behavior was observed for all doses of mineral fertilizer, except for the dose of $3 \mathrm{~g}$ that behaved $\mathrm{u}$ linearly as a function of the doses of manure, but the doses of 0 and $1 \mathrm{~g}$ of NPK were superior to the others when $200 \mathrm{~g}$ of manure were used, not statistically different, obtaining a maximum of 2.36 and $2.30 \mathrm{~g}$, respectively (Figure $3 \mathrm{~B}$ ).

Therefore, according to Suassuna et al. (2016) the reduction in leaf area exerts a direct effect under the photosynthetically active area, thus affecting the accumulation of biomass and interfering in the growth of seedlings. Carneiro et al. (2011) also observed additions on the dry matter content of the aerial part of clove rootstock, according to the doses of organomineral fertilizer used, however, did not decrease with the increase of them, possibly due to the doses used by such authors are less than that of this study.

Organic and mineral fertilization also influenced significantly the fresh and dry mass. In the fresh mass, the absence of NPK with increased doses of manure influenced positively with $31.31 \%$ increase in this variable for the greater bovine manure (Figure 3C), this fact is explained by Pereira et al. (2015) to which they suggest that the organic matter presents higher yields for the plants because it has a greater contribution of nutrients. However, when izou be useful NPK dosages quadratic behavior was observed for the same variable, demonstrating that even with increased dosages of the organic feedstock, provided beneficial effects to some degree. When using 1 and $2 \mathrm{~g}$ NPK with 79 and 82 g, respectively, bovine manure reached 4.44 and $4.33 \mathrm{~g}$ mass, declining from the respective doses. In addition, the $3 \mathrm{~g}$ NPK dose reduced the fresh weight of the seedlings from 4.70 to $2.18 \mathrm{~g}$ in the range of 0 to $400 \mathrm{~g}$ of cattle manure, equivalent to $53.51 \%$ loss.

In relation to the dry mass (Figure 3), the dose of $1 \mathrm{~g}$ of NPK associated to $229 \mathrm{~g}$ of bovine manure provided a greater accumulation of dry mass $(1.24 \mathrm{~g})$, compared to the absence of NPK (1.05 $\mathrm{g}$ in the dose of $290 \mathrm{~g}$ of 
manure) and the other dosages. It was found that there was no significant effect on the dose of $2 \mathrm{~g}$ of NPK, but the use of $3 \mathrm{~g}$ of NPK reduced $53 \%$ of dry biomass production with increased manure dosage. Similar results were found by Serrano et al. (2015) studying the production of cashew tree seedlings under increasing doses of NPK in different substrates. This variable is relevant to the production of seedlings for the rootstocks as a rich in stem assimilates assists in the healing process entity refer to future grafting. With this, the combination of organic and inorganic fertilizer in the correct proportion assists in the vigorousness of the cashew tree seedlings.

For the fresh mass variable of the root system, there was quadratic behavior for all doses of NPK a valued as a function of increasing doses of manure. However, the maximum $(5.64 \mathrm{~g})$ was reached when the plants were fertilized with manure $200 \mathrm{~g}$ and $1 \mathrm{~g}$ of NPK, these levels then gradually decreased as the dose was increased esterc independent NPK dose (Figure 4A). The dose of $1 \mathrm{~g}$ of NPK associated with $200 \mathrm{~g}$ of manure provided greater availability of nutrients, thus projecting a higher content of fresh root mass, thus increasing the vigor of the plants, because the higher the root system increment, the greater the capacity of the plants develop, this being due to reach greater depths and consequently to have greater access to the absorption of water and nutrients. According to Magalhães et al. (2017) the combination of mineral inputs with organic bovine inputs provides a positive influence on the accumulation of biomass.
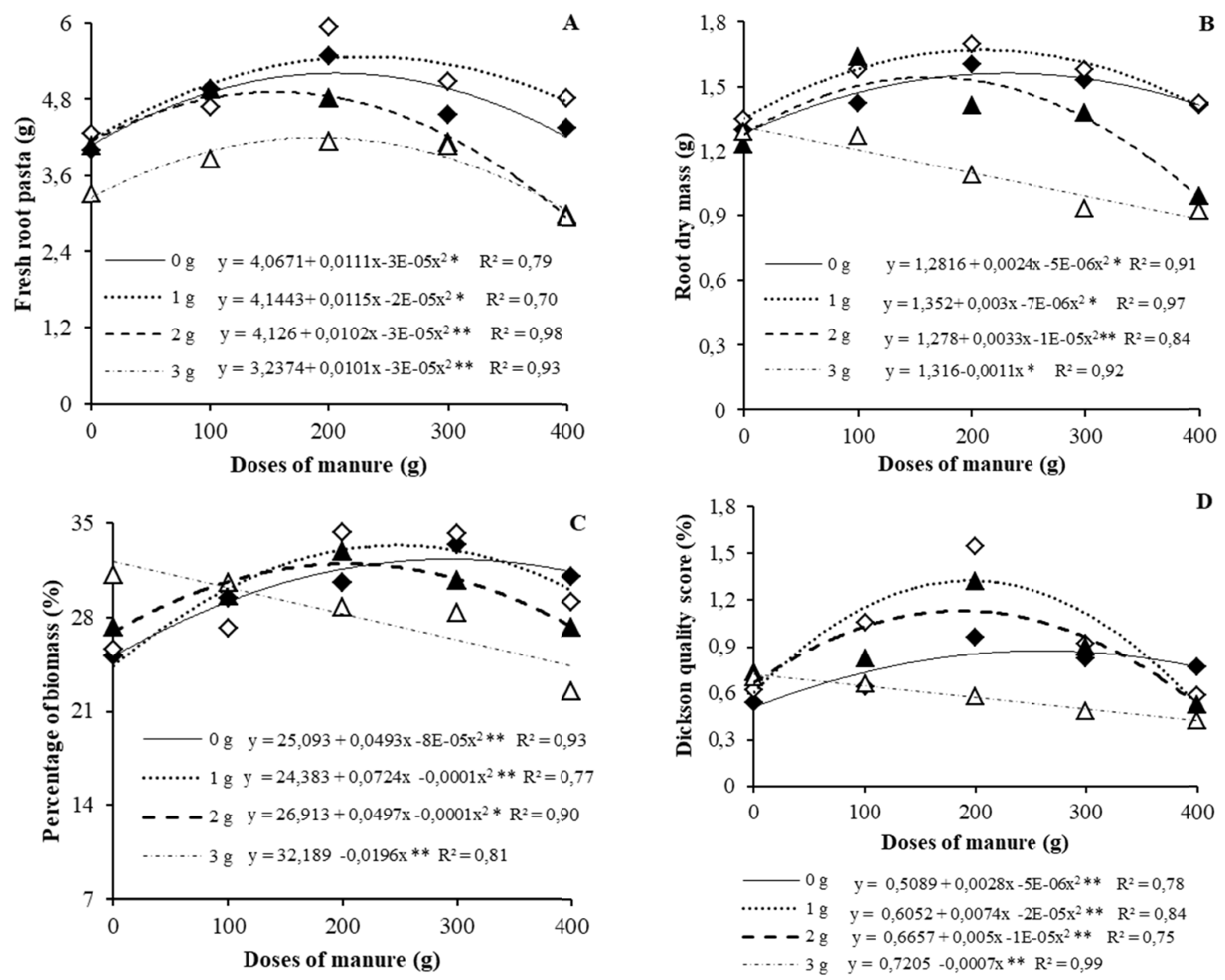

Figure 4. Fresh (A) and dry (B) mass of root, percentage of biomass (C) and quality index (D) in cashew tree seedlings submitted to organic and mineral fertilization. UFCG, Pombal-PB, 2017

There was adjustment of the dots to the quadratic model for the doses of 0,1 and $2 \mathrm{~g}$ of NPK and for the dose of $3 \mathrm{~g}$ a decreasing linear behavior was observed, that is, the increase of the dose of manure reduced the content of dry mass accumulated by the plant. This fact can be explained by the high concentration of NPK which may have caused the nutrients unavailability to be absorbed by the plant. For the dry mass, the dose combination of 1 $\mathrm{g}$ NPK and $200 \mathrm{~g}$ manure was the interaction that obtained the best yield in this variable reaching a maximum of 
$1.69 \mathrm{~g}$ (Figure 4B). Results similar to this work were observed by Serrano et al. (2013) evaluating the production of 'CCP 06' cashew rootstocks verified that high doses of NPK caused a reduction in the values of dry mass accumulated by the plant.

The percentage of biomass (PB) in the absence of NPK was adjusted to the quadratic model with maximum point at $308 \mathrm{~g}$ of manure with $\mathrm{PB}$ of $32.68 \%$, declining from that dose (Figure 4C). Furthermore, it was verified that $1 \mathrm{~g}$ of NPK provided a greater accumulation of biomass, since it obtained $37 \%$ of biomass in the estimated dose of $300 \mathrm{~g}$, whereas the dose of $2 \mathrm{~g}$ of NPK reached 33\% when associated with $249 \mathrm{~g}$ of manure bovine. However, the dose of $3 \mathrm{~g}$ of NPK was adjusted by a linear regressive model, equipotente to $24.35 \%$ reduction with increase of the organic input.

The excess of the organic input supposedly may have caused inhibition of some essential nutrients, according to Costa et al. (2012), found that the levels of $\mathrm{Zn}$ (zinc) and S (sulfur) increased dramatically with increasing percentages of the organic compound causing phytotoxicity. These authors further conclude that the use of $20 \%$ of the compound is sufficient for seedling production, as well as in this work.

Dickson Quality Index (DCI) is an important variable for diagnostic air quality seedlings for allies the vigorosidade and the equilibrium distribution of biomass as a correlation result of various morphological import before (Prates et al., 2012). Thus, it was observed that the dosage of $1 \mathrm{~g}$ of NPK with $200 \mathrm{~g}$ of manure obtained IQD of 1.28, while the use of $2 \mathrm{~g}$ of NPK provided in association with $200 \mathrm{~g}$ of manure had IQD of 1.1 and the absence of NPK at the dose of $280 \mathrm{~g}$ of manure received $0.90 \mathrm{IQD}$. Corroborating with the other growth variables, the dose of $3 \mathrm{~g}$ of NPK under these conditions decreased $38.86 \%$ the quality of the seedlings as the doses of manure increased, probably due to this dosage of the mineral fertilizer causing phytotoxicity.

Considering the exposed, it is assumed that the best combination for production of cashew tree seedlings was obtained using the dose of $1 \mathrm{~g}$ of NPK conciled with $200 \mathrm{~g}$ of bovine manure, because, as affirm Freitas et al. (2017) the higher the quality index of the more standardized seedlings these are. The reduction will be observed in the quality of seedlings from $300 \mathrm{~g}$ manure and NPK $3 \mathrm{~g}$ dose is due to the excess salts from both the manure as fertilizer, these respective concentrations, similar results were found by Oliveira et al. (2015) when studying guava rootstocks under different sources and proportions of organic materials, which observed higher quality of seedlings in the proportion of $40 \%$ of the organic material declining with increasing proportion.

\section{Conclusions}

Under the conditions of this work, bovine manure provided an improvement in the growth of the rootstocks, but their excess may damage the cashew tree seedlings;

The use of NPK fertilizer promoted increase in the development of the seedlings, however the use of $3 \mathrm{~g}$ of NPK was not satisfactory causing phytotoxicity;

The organic and mineral combination ( $1 \mathrm{~g}$ of NPK and $200 \mathrm{~g}$ of bovine manure) provided the largest increases in vegetative growth and shoot quality characteristics in the cashew tree.

\section{References}

Aguiar, A. V., Cavalcante, L. F., Silva, R. M., Dantas, T. A. G., \& Santos, E. C. (2017). Effect of biofertilization on yellow passion fruit production and fruit quality. Revista Caatinga, 30(1), 136-148. https://doi.org/10.1590/ 1983-21252017v30n115rc

Araújo, J. P. P. (2013). Agronegócio caju: Práticas e inovações (p. 532). Brasília, DF: Embrapa Informação Tecnológica.

Araújo, L. G., \& Araújo, R. M. (2014). Cadeia Produtiva da Cajucultura do RN: Um Estudo de Caso de Serra do Mel no Universo das Redes Sociais, do Nacional ao Local. UNOPAR Científica Ciências Jurídicas e Empresarias, 15(1), 71-81. https://doi.org/10.17921/1517-9427.2014v15n1p\%25p

Barros, L. M., Pimentel, C. R. M., Corrêa, M. P. F., \& Mesquita, A. L. M. (1993). Recomendações técnicas para a cultura do cajueiro-anão-precoce (p. 65). Fortaleza, CE: EMBRAPA-CNPAT.

Carneiro, P. A. P., Lopes, P. S. N., Oliveira, N. C. C., Fernandes, L. A., \& Melo, B. (2011). Produção de porta-enxerto de limão cravo, em resposta à adubação organomineral. Bioscience Journal, 27(3), 427-432.

Cavalcante, I. H. L., Martins, A. B. G., Silva Júnior, G. B., Rocha, L. F., Falcão Neto, R., \& Cavalcante, L. F. (2011). Adubação orgânica e intensidade luminosa no crescimento e desenvolvimento inicial da pitaya em Bom Jesus-PI. Revista Brasileira de Fruticultura, 33(3), 970-982. https://doi.org/10.1590/S0100-294520110 05000086 
Cavalcanti Júnior, A. T. (2013). Propagação assexuada do cajueiro. In J. P. P. Araújo (Ed.), Agronegócio caju: Práticas e inovações (pp. 241-274). Brasília, DF: Embrapa.

Chang, E. H., Chung, R. S., \& Tsai, Y. H. (2007). Effect of different application rates of organic fertilizer on soil enzyme activity and microbial population. Soil Science \& Plant Nutrition, 53(2), 132-140. https://doi.org/ 10.1111/j.1747-0765.2007.00122.x

Costa, E., Ferreira, F. A., Silva, P. N. L., \& Nardelli, E. M. V. (2012). Diferentes composições de substratos e ambientes protegidos na formação de mudas de pé-franco de tamarindeiro. Revista Brasileira de Fruticultura 34(4), 1189-1198. https://doi.org/10.1590/S0100-29452012000400028

Costa, L. C. B., Rosal, L. F., Pinto, J. E. B. P., \& Bertolucci, S. K. V. (2008). Efeito da adubação química e orgânica na produção de biomassa e óleo essencial em capim-limão (Cymbopogon citratus). Revista Brasileira de Plantas Medicinais, 10(1), 16-20.

Dickson, A., Leaf, A. L., \& Hosner, J. F. (1960). Quality appraisal of white spruce and white pine seedling stock in nurseries. Revista Forestry Chronicle, 36(1), 10-13. https://doi.org/pdf/10.5558/tfc36010-1

Emon, R. M., Gregorio, G. B., Nevame, A. Y. M., Islam, M. M., Islam, M. R., \& Ye-Yang, F. (2015). Morpho-Genetic Screening of the Promising Rice Genotypes under Salinity Stress. Journal of Agricultural Science, 7(5), 94-111. https://doi.org/10.5539/jas.v7n5p94

Ferreira, D. C. C., Braga, G. M. S., Moura, J. A., Viana, J. B., \& Gondim Neto, L. (2016a). A Importância do caju no Ceará e seus subprodutos. Encontros Universitários da UFC, 1(1), 4183-4195.

Ferreira, D. F. (2011). Sisvar: A computer statistical analysis system. Ciência e Agrotecnologia (UFLA), 35(6), 1039-1042. https://doi.org/10.1590/S1413-70542011000600001

Ferreira, L. G., Negrini Junior, E., Valente, J. P., Távora, C., \& Ferreira, C. B. (2016b). Avaliação de Métodos de Enxertia para Mangueira e Cajueiro na Baixada Cuiabana. Ensaios e Ciencia: Biologicas, Agrarias e Saúde, 20(3), 126-130. https://doi.org/10.17921/1415-6938.2016v20n3p\%25p

Freitas, E. C. S., Paiva, H. N., \& Oliveira Neto, S. N. (2017). Crescimento e qualidade de mudas de Cassia grandis Linnaeus $f$. em resposta à adubação fosfatada e calagem. Ciência Florestal, 27(2), 509-519. https://doi.org/ $10.5902 / 1980509827732$

IBGE (Instituto Brasileiro de Geografia e Estatística). (2016). Levantamento Sistemático da Produção Agrícola: Pesquisa mensal de previsão e acompanhamento das safras agrícolas no ano civil (Vol. 25, No. 2, p. 45). Rio de Janeiro, RJ: Fundação Instituto Brasileiro de Geografia e Estatistica.

Köppen, W. (1948). Climatologia: con un estudio de los climas de la tierra (p. 479). México, MEX: Fondo de Cultura Econômica.

Magalhães, C. A. S., Morales, M. M., Rezende, F. A., \& Langer, J. (2017). Eficiência de fertilizantes organominerais fosfatados em mudas de eucalipto. Revista Scientia Agraria, 18(4), 80-85. https://doi.org/ 10.5380/rsa.v18i4.52247

Melo, A. S., Costa, C. X., Brito, M. E. B., Viégas, P. R. A., \& Silva Júnior, C. D. (2007). Produção de mudas de mamoeiro em diferentes substratos e doses de fósforo. Revista Brasileira de Ciências Agrárias, 2(4), 257-261. https://doi.org/10.5039/agraria.v2i4a1838

Murthy, K. N., Kumar, K. V., Bhagavan, S., Subbaiah, C. C., \& Kumaran, P. M. (1985). A rapid non-destructive method of estimating leaf area in cashew. Acta Horticulturae, 108(8), 46-48. https://doi.org/10.17660/Acta Hortic. 1985.108.8

Oliveira Neto, H. T., Gondim, A. R. O, Sá, F. V. S., Souto, L. S., Brito, M. E. B., Silva, M. S., \& Lira, R. P. (2017). Growth, gas exchanges and production of beet cv. katrina under organo-mineral fertilization. Bioscience Journal, 33(5), 1126-1133. https://doi.org/10.14393/BJ-v33n5a2017-36554

Oliveira, F. T., Hafle, O. M., Mendonça, V., Moreira, J. N., Pereira Júnior, E. B., \& Rolim, H. O. (2015). Respostas de porta-enxertos de goiabeira sob diferentes fontes e proporções de materiais orgânicos. Comunicata Scientiae, 6(1), 17-25.

Pereira, E. C., Câmara, F. M. M., Mendonça, V., Costa, J. M., Carneiro, J. V., \& Silva, R. M. (2015). Fontes, proporções de materiais orgânicos e doses de fósforo na produção de mudas de pinha. Agropecuária Científica no Semiárido, 11(3), 84-96. 
Pereira, E. C., Dantas, L. L. G. R., Almeida, J. P. N., Mendonça, L. F. M., \& Mendonça, V. (2011). Fontes e doses de nitrogênio na produção de porta-enxertos de pitombeira (Talisia esculenta Radlk). Revista Verde de Agroecologia e Desenvolvimento Sustentável, 6(3), 197-202.

Prates, F. B. S, Lucas, C. S. G., Sampaio, R. A., Brandão Júnior, D. S., Fernandes, L. A., \& Zuba Júnior, G. R. (2012). Crescimento de mudas de pinhão-manso em resposta a adubação com superfosfato simples e pó-de-rocha. Revista Ciência Agronômica, 43(2), 207-213. https://doi.org/10.1590/S1806-66902012000 200001

Serrano, L. A. L., Hawerroth, F. J., Taniguchi, C. A. K.., \& Melo, D. S. (2013). Substratos comerciais e adubo de liberação lenta (NPK 14-14-14) na produção de porta-enxerto de cajueiro. Boletim de Pesquisa e Desenvolvimento, 85 (p. 24) Fortaleza, CE: Embrapa Agroindústria Tropical.

Serrano, L. A. L., Melo, D. S., Martins, T. S., Taniguchi, C. A. K., \& Hawerroth, F. J. (2015). Produção de Mudas de Cajueiro 'CCP 76' em Diferentes Substratos e Doses de Adubo de Liberação Lenta (NPK 16-08-12). Boletim de Pesquisa e Desenvolvimento, 105 (p. 30). Fortaleza, CE: Embrapa Agroindústria Tropical.

Suassuna, C. F., Ferreira, N. M., Sá, F. V. S., Bertino, A. M. P., Mesquita, E. F., Paiva, E. P., ... Bertino, A. M. P. (2016). Produção de mudas de cajueiro anão precoce cultivado em diferentes substratos e ambientes. Revista Agrarian, 9(33), 197-209.

Taiz, L., Zeiger, E., Moller, I. M., \& Murphy, A. (2017). Fisiologia e desenvolvimento vegetal (6nd ed., p. 888). Porto Alegre, RS: Artmed.

Ximenes, C. H. M. (1995). Adubação mineral de mudas de cajueiro-anão-precoce cultivada em diferentes substratos (p. 102, Mestrado Dissertação, Universidade Federal do Ceará, Fortaleza).

\section{Copyrights}

Copyright for this article is retained by the author(s), with first publication rights granted to the journal.

This is an open-access article distributed under the terms and conditions of the Creative Commons Attribution license (http://creativecommons.org/licenses/by/4.0/). 